\title{
ANALISIS FILOGENETIK GARCINIA SPP. BERDASARKAN SEKUENS GEN rRNA
}

\author{
(Phylogenetic Analysis of Garcinia spp. Based on rRNA Gene Sequences)
}

\author{
Rara Erlina Oktafia dan Badruzsaufari \\ Fakultas Matematika dan Ilmu Pengetahuan Alam, Program Studi Biologi, Universitas Lambung \\ Mangkurat, Jalan A. Yani Km.36, Banjarbaru, Indonesia \\ Penulis koresponden: raraerlina@gmail.com
}

Article Submitted: 07-04-2021

Article Accepted: 29-05-2021

\begin{abstract}
Garcinia genus has a complicated taxonomy due to the high similarities in morphological characters of its members. The phylogenetic analysis on Garcinia species based on rRNA gene sequence intended to find out the evolutionary relationship amongst the species. This research employed 20 sequences of rRNA gene of Garcinia species selected from the GenBank of the National Center for Biology Information (NCBI). The sequences were aligned using ClustalW with the MEGA $\mathrm{X}$ application. A phylogenetic tree was constructed Maximum Likelihood method approximation and Kimura 2-parameter model. The results of the analysis showed that the cladogram had monophyletic parameter properties and classified into 3 clades. Clade I consisted of G. celebica, G. hombroniana, G. opaca, G. mangostana, G. malaccensis, $G$. penangiana, G. scortechinii, G. hanburyi, and G. urophylla. Clade II included G. atroviridis, G. bancana, G. forbesii, G. griffithii, G. cowa, G. nigrolineata, G. globulosa, and G. parvifolia. Clade III composed of G. rostrata, G. nervosa, and G. praininiana. The species of Garcinia considered the most primitive and the closet to their ancestor is G. nervosa.
\end{abstract}

Keywords: Phylogenetic; Garcinia; Cladogram, Maximum Likelihood, rRNA gene

\section{PENDAHULUAN}

Garcinia atau dikenal sebagai tumbuhan manggis-manggisan merupakan salah satu genus dari famili Clusiaceae atau Guttiferae. Garcinia tersebar di Asia tenggara, mulai dari Thailand, Malaysia, Indonesia hingga Filiphina (Te-Chato, 2007). Terdapat lebih dari 400 spesies Garcinia tersebar di seluruh dunia dan diperkirakan 100 spesies diantaranya tumbuh di Indonesia (Santoso dkk. 2019). Spesies yang paling terkenal dari genus Garcinia adalah manggis (Garcinia mangostana) atau queen of fruits. Manggis (Garcinia mangostana) menjadi salah satu komoditas eskspor bagi Indonesia yang bernilai ekonomi cukup tinggi (Sinaga dkk. 2010).

Kalimantan menjadi pusat keanekaragaman Garcinia di Indonesia. Hal tersebut dikarenakan sebanyak 25 spesies Garcinia ditemukan di sana (Uji, 2007). Salah satu kerabat manggis di Kalimantan yang mulai langka dan perlu dilestarikan adalah Mundar (Garcinia forbesii) (Hujjatusnaini, 2016). Mundar (Garcinia forbesii) dicirikan dengan buah berbentuk bulat, serta daging buah berwarna putih. Rasa buahnya manis, namun terdapat rasa asam pada bagian yang menempel pada biji (Noor dkk. 2015). Kelangkaan mundar terjadi dikarenakan adanya kebakaran hutan, 
illegal logging, serta penggunaan lahan secara tidak bijak (Hujjatusnaini, 2016).

Kelangkaan yang terjadi harus segera diatasi dengan melakukan konservasi dan budidaya. Namun, menurut Uji (2007) budidaya manggis memiliki beberapa kelemahan, yaitu lambatnya pertumbuhan tanaman, panjangnya masa juvenil, serta adanya penyakit getah kuning pada buah. Selain itu, Sari dan Gafurhan (2013) menyatakan bahwa Garcinia juga memiliki masalah taksonomi yang kompleks. Beberapa jenis Garcinia yang ditemukan di alam sulit dibedakan karena memiliki kemiripan morfologi. Berdasarkan permasalahan-permasalahan di atas khususnya dalam pengembangan budidaya tanaman manggis di Indonesia, maka diperlukan penelitian mengenai kekerabatan antar spesies Garcinia untuk meningkatkan keberhasilan dalam pemuliaannya. Dalam hal ini, analisis filogenetik merupakan metode yang dirasa tepat untuk mengetahui hubungan kekerabatan Garcinia.

Analisis filogenetik merupakan salah satu metode yang umum digunakan untuk mengetahui keanekaragaman suatu organisme melalui rekontruksi hubungan kekerabatan. Analisis filogenetik akan memberikan informasi terkait bagaimana proses evolusi yang dialami suatu organisme, yang kemudian akan direpresentasikan dalam sebuah sistem percabangan (pohon filogenetika). Karakter yang sama akan menjadi dasar dalam menganalisis hubungan antar spesies yang diamati (Dharmayanti, 2011). Analisis filogenetik bertujuan untuk mengelompokkan serta memberikan informasi terkait evolusi kekerabatan antar spesies Garcinia agar dapat dimanfaatkan dalam usaha konservasi. Penelitian ini menggunakan data sekunder beberapa sekuens nukleotida genus Garcinia, yaitu berupa gen rRNA yang mencakup 18S rRNA, ITS1, 5.8S rRNA, ITS2, dan 28S rRNA (Elela dan Nazar, 1997).

\section{METODE PENELITIAN}

Metode penelitian menggunakan data sekunder yang diambil GenBank di National Center for Biology Information (NCBI) berupa sekuens nukleotida mencakup 18S rRNA, ITS1, 5.8S rRNA, ITS2 dan 28S rRNA dari genus Garcinia. Spesies out group yang dipilih adalah rambutan (Nephelium lappaceum). Spesies out group diperlukan sebagai pembanding dalam menentukan spesies. Pembanding berfungsi agar terbentuk filogenetik yang jelas dan kuat untuk mengklasifikasikan suatu kekerabatan antar spesies (Putri, 2015). Data sekuens ditulis dalam format teks (Notepad) dan dikonversi menjadi format MEDA serta dilakukan analisis pensejajaran (alignment) dengan ClustalW dengan bantuan aplikasi Molecular Evolutionary Genetic Analysis Software versi 10 atau MEGA X (Tamura dkk., 2007). Ujung 5' dan 3'sekuen semua spesies Garcinia diratakan dengan dipangkas (trimmed), kecuali spesies out group.

\section{Analisis filogenetik}

Pohon filogenetik dikonstruksi dengan metode 'Maximum Likelihood' menggunakan bootstrap 1000 ulangan dengan model Kimura 2-parameter. Konstruksi dilakukan dengan perangkat lunak MEGA X (Tamura dkk., 2007).

\section{HASIL DAN PEMBAHASAN}

Hasil rekonstruksi pohon filogenetik dari 20 sampel sekuens nukleotida rRNA genus Garcinia dan spesies out group berupa rambutan (Nephelium lappaceum) ditampilkan pada bootstrap tree (Gambar 1) dan original tree (Gambar 2). Pendekatan maximum likelihood digunakan untuk mengetahui evolusi yang lebih komplek (Dharmayanti, 2011). Nilai boostrap ditunjukkan pada angka yang terletak pada cabang-cabang pohon filogenetika (Gambar 2). Nilai tersebut memperlihatkan tingginya akurasi percabangan yang terbentuk. Nei dan Kumar (2000) menyatakan bahwa semakin 
besar nilai bootstrap, maka semakin tinggi pula tingkat akurasi topologi pohon hasil rekontruksi tersebut. Hal ini menunjukan bahwa yakni Klad I dan II, membentuk cabang dan buku (node) yang signifikan, serta Klad III diyakini cukup kuat terpisah dari dua klad yang pertama.

Gambar 1 menunjukkan bahwa pohon filogenetik tersusun secara monofiletik yang menggambarkan alur evolusi dari yang tertua sampai yang termuda. Hasil analisis filogenetika pada kladogram menunjukkan bahwa hubungan kekerabatan terbagi menjadi 3 klad. Klad I terdiri dari 9 spesies, diantaranya G. celebica, G. hombroniana,
G. opaca, G. mangostana, G. malaccensis, G. penangiana, G. scortechinii, G. hanburyi, dan $G$. urophylla. Jenis-jenis tersebut tergabung dalam satu klad yang sama, dikarenakan banyaknya kemiripan pada urutan sekuens. Sembilan spesies tersebut memiliki tingkat kekerabatan yang tinggi, hal tersebut sesuai dengan hasil penelitian yang dilaporkan Sinaga dkk. (2010). Selain itu, kekerabatan terbukti pada $G$. mangostana dan $G$. malaccensis yang memiliki ciri-ciri fenotip yang sangat mirip, hanya saja $G$. malaccensis memiliki ukuran yang lebih kecil (Uji, 2007).

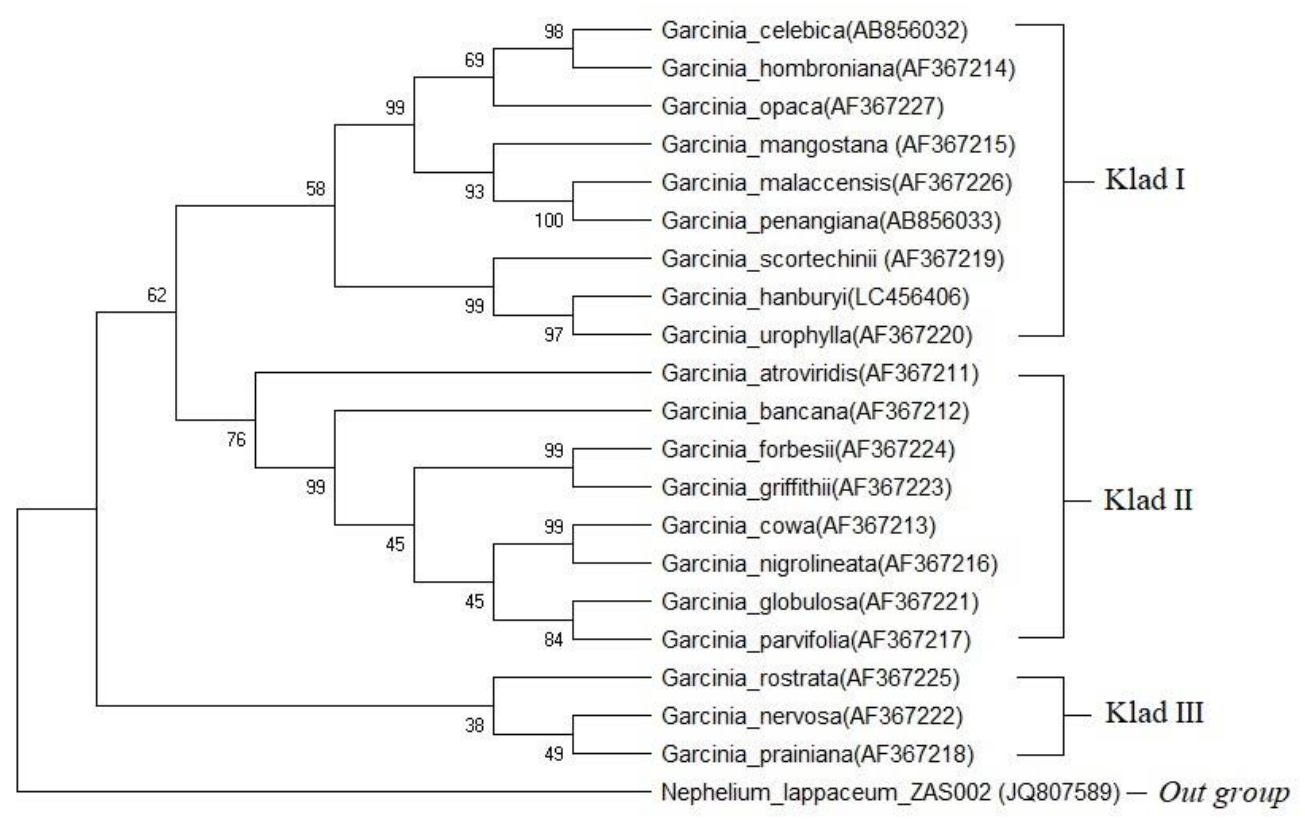

Gambar 1. Kladogram Garcinia berdasarkan sekuens gen rRNA dengan bootstrap 1000× 


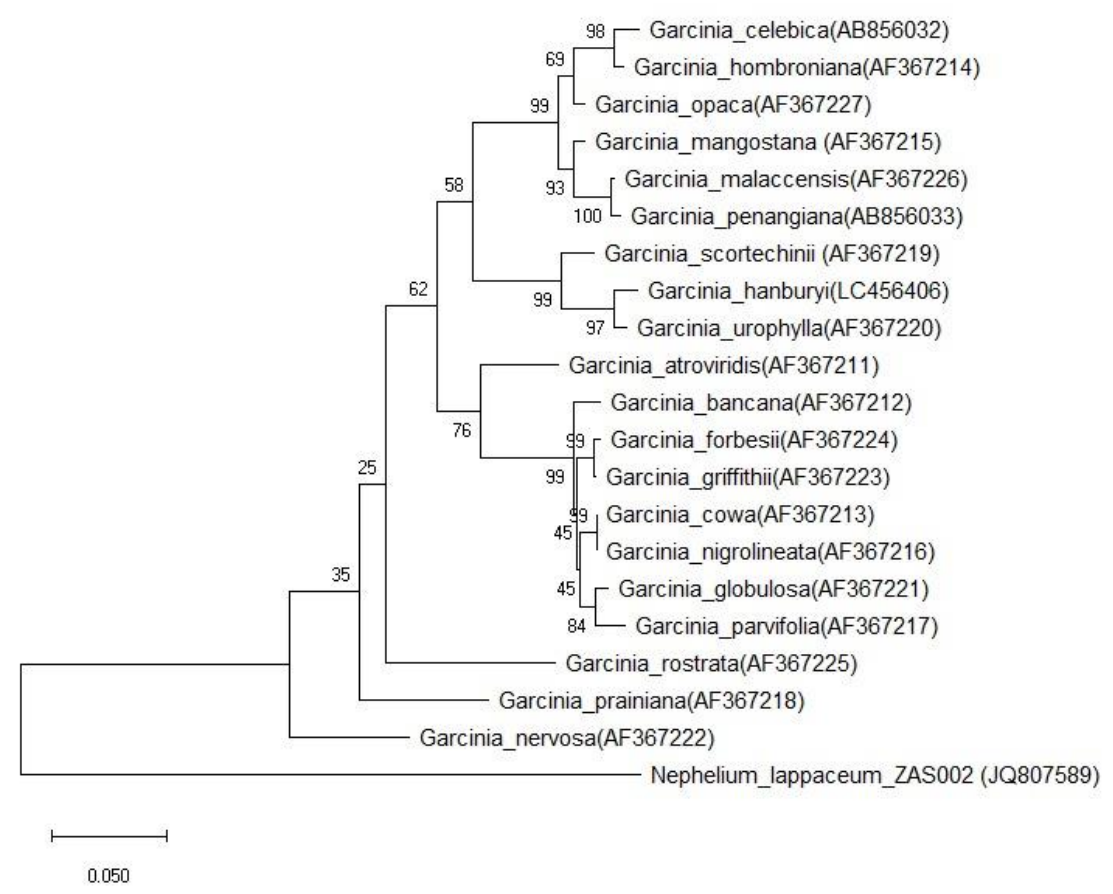

Gambar 2. Pohon filogenetik original melalui pendekatan 'maximum likelihood' pada Garcinia berdasarkan sekuens gen rRNA.

Perbandingan hasil persamaan morfologi berupa jumlah stigma, warna bunga, warna buah serta rasa buah, menunjukkan manggis ( $G$. mangostana) cenderung lebih mirip dengan $G$. malaccensis daripada G. hombroniana (Sinaga dkk. 2010). Berdasarkan kesamaan tersebut, Sinaga dkk. (2010) menyatakan bahwa G. mangostana merupakan hibrida antara G. malaccensis dan G. hombroniana.

Klad II terdiri dari 8 spesies, yaitu $G$. atroviridis, G. bancana, G. forbesii, $G$. griffithii, $G$. cowa, G. nigrolineata, $G$. globulosa, dan G. parvifolia. Banyaknya kemiripan antar sekuens yang dimiliki membuat kedelapan spesies tersebut masuk dalam klad yang sama. Selain itu, semua anggota klad memiliki daerah persebaran yang sama di Indonesia, yaitu Sumatra (Uji, 2007). Pada klad II terdapat buah mundar (G. forbesii) serta kerabat dekatnya kandis gajah (G. griffithii) dan asam kandis ( $G$. cowa) yang juga diperkirakan mempunyai kandungan fitokimia dan metabolisme yang serupa, sehingga memudahkan untuk mengkaji buah mundar (Lim, 2012).

Klad III terdiri dari $G$. rostrata, $G$. nervosa, dan $G$. praininiana, ketiga spesies tersebut masuk dalam klad yang sama dikarenakan banyaknya persamaan urutan sekuens yang dimilikinya. Persamaan morfologi ketiga spesies terletak pada buahnya yang berbentuk bulat dan termasuk edible fruit. Selain itu, G. rostrata, $G$. nervosa, dan $G$. praininiana memiliki daerah persebaran yang sama di Indonesia, yaitu Kalimantan (Uji, 2007). Namun, diantara 3 klad yang terbentuk, klad III merupakan klad yang memiliki anggota dengan tingkat kekerabatan paling jauh jika dibandingkan dengan genus Garcinia yang lainnya.

Garis pada pohon filogenik dapat menunjukkan jarak evolusi antar spesies dan kesamaan moyang (Mello, 2018). Jarak evolusi dapat dilihat pada panjang pendeknya garis yang terbentuk. Semakin panjang garis, maka semakin jauh jarak evolusinya dan dapat dikatakan spesies 
tersebut memiliki karakter lebih maju. Sedangkan, semakin pendek garisnya, menandakan suatu spesies memiliki karakter yang lebih primitif. Garis yang dihasilkan menunjukkan $G$. nervosa, memiliki garis evolusi tependek dan dapat dianggap paling lebih dekat moyang semua manggismanggisan yang dianalisis (Gambar 2).

\section{KESIMPULAN}

Hasil dari analisis filogenetik dari 20 spesies Garcinia berdasarkan sekuens 5,8S rRNA dapat disimpulkan bahwa kladogram bersifat monofiletik dan terbagi dalam 3 klad. Klad I terdiri dari G. celebica, $G$. hombroniana, G. opaca, G. mangostana, $G$. malaccensis, G. penangiana, G. scortechinii, G. hanburyi, dan G. urophylla. Klad II terdiri dari terdiri dari $G$. atroviridis, $G$. bancana, G. forbesii, G. griffithii, G. cowa, $G$. nigrolineata, $G$. globulosa, dan $G$. parvifolia. Kemudian klad III terdiri dari $G$. rostrata, G. nervosa, dan G. praininiana. $G$. nervosa dianggap paling primitif berdasarkan garis evolusinya.

\section{DAFTAR PUSTAKA}

Dharmayanti, N. L. P. I. 2011. Filogenetika Molekular: Metode Taksonomi Organisme Berdasarkan Sejarah Evolusi. WARTAZOA. 21(1), 1-10.

Elela, S. A., \& Nazar, R. N. 1997. Peran rRNA 5,8S dalam Translokasi Ribosom. Penelitian Asam Nukleat. 25(9), 1788-1794.

Fitmawati, A. Swita, N. Sofyanti., \& Herman. 2013. Analisis Kekerabatan Morfologi Mangifera dari Sumatera Tengah. Floribunda. 4(7), 169-174.

Hujjatusnaini, N. 2016. Konservasi Kawasan Hutan Di Lamandau dengan Konsep Bioremiadiasi dan Adat Dayak Kaharingan. Jurnal BIOEDUKASI. 4(2), 498-510.
Lim T.K., 2012. Garcinia forbesii. In: Edible Medicinal And Non-Medicinal Plants. Springer, Dordrecht

Mello, B. 2018. Estimating TimeTrees with MEGA and the TimeTree Resource. Mol. Biol. Evol. 35(9):2334-2342

Nei, M., \& Kumar, S. 2000. Molecular Evolution and Phylogenetics. Oxford University Press, New York.

Noor, M., M. Saleh., \& H. Subagio. 2015. Potensi Keanekaragaman Tanaman Buah-Buahan di Lahan Rawa dan Pemanfaatannya. PROS SEM MASY BIODIV INDON. 1(6), 1348-1358. https://doi.org/10.13057/psnmbi/m010 615

Putri, M. A. 2015. Variasi Genetik Rotan Berdasarkan Penanda DNA Barcode matK, rbcL, dan ITS Pada Pangkalan Data Genbank. Skripsi. Institut Pertanian Bogor, Bogor.

Santoso, P. J., E. Mansyah., \& A. Pancoro. 2019. Klarifikasi Keanggotaan Manggis 'Malinau' Dalam Species Garcina mangostana Menggunkan Analisis Filogenik. Jurnal Pertanian Tropik. 6(1), 43-48.

Sari, R., \& M. Gafurhan. 2013. Manggis Membulat Telur dari Kalimantan Barat. Floribunda. 4(6), 154-159.

Sinaga, S., Sobir, R. Poerwanto, H. Aswidinnoor., \& D. Duryadi. 2010. Genetic Diversity and The Relationship Between The Indonesian Mangosteen (Garcinia mangostana) and The Related Species Using Isozyme Markers. Jurnal Natur Indonesia. 13(1), 53-58. https://doi.org/10.31258/jnat.13.1.5358 
Tamura K, J. Dudley, M. Nei \& S. Kumar. 2007. MEGA4: Molecular Evolutionary Genetics Analysis (MEGA) software version 4.0. Molecular Biology and Evolution 24:1596-1599.

Te-Chato, S. 2007. Floral and Fruit Morphology of Some Species In
Garcinia spp. Songklanakarin Journal of Science and Technology. 29(2), 245-252.

Uji, T. 2007. Keanekaragaman, Persebaran, dan Potensi Jenis-Jenis Garcinia di Indonesia. Hayati. 12, 129-135. 